\title{
A Novel Acoustic Sandwich Panel Based on Sheep Wool
}

\author{
Daniela-Roxana Tămaş-Gavrea ${ }^{1}$ ** , Tünde-Orsolya Dénes ${ }^{1}$, Raluca Iştoan ${ }^{1}$, \\ Ancuţa Elena Tiuc ${ }^{2}$ D, Daniela Lucia Manea ${ }^{1}$ and Ovidiu Vasile ${ }^{3}$ \\ 1 Department of Civil Engineering and Management, Technical University of Cluj-Napoca, \\ 28 Memorandumului Street, 400114 Cluj-Napoca, Romania; orsolya.denes@ccm.utcluj.ro (T.-O.D.); \\ ralucafernea@mail.utcluj.ro (R.I.); daniela.manea@ccm.utcluj.ro (D.L.M.) \\ 2 Department of Environmental Engineering and Sustainable Development Entrepreneurship, Technical \\ University of Cluj-Napoca, 103-105 Muncii Boulevard, 400641 Cluj-Napoca, Romania; \\ ancuta.tiuc@imadd.utcluj.ro \\ 3 Department of Mechanics, University Politehnica of Bucharest, 313 Splaiul Independenţei, 060042 Bucharest, \\ Romania; ovidiu_vasile2002@yahoo.co.uk \\ * Correspondence: roxana.tamas@ccm.utcluj.ro
}

Received: 13 January 2020; Accepted: 5 February 2020; Published: 7 February 2020

check for updates

\begin{abstract}
The aim of this paper is to propose a novel sandwich panel, which would be suitable for sound absorption and airborne sound insulation, used as applied cladding or independent lightweight partition wall. As far as the authors are concerned, this is the first sheep wool-based sandwich panel using only natural materials. The structure was prepared using hydrated lime-based composite face sheets and a sheep wool-based core. Several parameters of the sandwich panel were determined, including sound absorption coefficient, airborne sound insulation, thermal conductivity, thermal resistance, compressive strength, and bending strength, respectively. The results indicate that the maximum sound absorption value of 0.903 was obtained at the frequency of $524 \mathrm{~Hz}$ in the case of the unperforated sample, 0.822 at $536 \mathrm{~Hz}$ in the case of the sample with $10 \%$ perforations, 0.780 at $3036 \mathrm{~Hz}$ in the case of the sample with $20 \%$ perforations, and 0.853 at $3200 \mathrm{~Hz}$ in the case of the sample with $30 \%$ perforations. The registered airborne sound insulation index of the panel was $38 \mathrm{~dB}$. Based on the obtained data, it can be concluded that the studied panel recorded comparable values with other synthetic noise control solutions, which are suitable as applied cladding or an independent lightweight partition wall, with good acoustic properties.
\end{abstract}

Keywords: sound absorption; mechanical properties; natural composite; applied cladding; lightweight partition wall

\section{Introduction}

The use of materials that have a reduced impact on the environment is of great importance, especially today, when the consequences of human intervention on the biosphere have become alarming. Many of the currently manufactured coating materials are of synthetic origin, which, during their service life, might affect the well-being of humans by emitting harmful substances, such as formaldehyde or other volatile organic compounds. These materials, if inappropriately discarded, can damage the natural environment as well. In the building industry, the use of surface treatments is suitable to the field of acoustics. These functional coating panels are usually made of synthetic foams or perforated sandwich panels. In light of environmental consciousness, new materials should be designed, which would perform similarly or better than the existing synthetic ones. These new coating surfaces might be formulated with natural or recycled materials. 
Natural materials and natural materials-based composites have several advantages, such as easy processing [1], use of local materials [2], high availability [3], carbon sequestration during the plant's life [4], and, after the end of service life, they can be introduced into the natural environment without causing damage [5]. Besides these advantages, they also possess a few disadvantages, such as low fibre-matrix compatibility [6], high risk of attack of microorganisms [7], fibre defects, and structural differences that can lead to variable mechanical strengths [8].

A sandwich panel is constructed by assembling multiple layers of different materials. In general, a sandwich structure consists of a core that is placed between two faces or skins [9]. Regarding the use of the materials, sandwich panels may be natural, hybrid, or fully synthetic. There are several studies reported in the literature about natural and hybrid sandwich structures, constructed with various materials, but only a few of these assess the sandwich panel's acoustic properties [10-13]. The majority of them focuses on mechanical strength. These structures are mainly used in engineering, automotive, and aeronautical applications. The skins are mainly produced from hardwood plates [14], veneer [15], flax fibers-epoxy resin composite [10,12], bamboo, and cotton bound with a vinyl ester matrix [11], natural silk fiber and epoxy resin [16], glass fiber mat [17,18], aluminum sheets [19,20], and carbon fiber-epoxy resin composite [13]. Similarly, the core of the structures could be prepared from mushroom foam [14], agglomerated cork [10,13], balsa wood [11,12], pine wood [11], medium density fiberboard [20], a textile fibers-bone glue composite [15], natural fibers (palm leaf, coconut, raffia, oil palm) and polyester resin [17], natural fibers (jute and hemp) and epoxy resin [18,19], and synthetic foams [16]. The manufacturing method of these sandwich structures also varies from gluing the elements together [14], using a vacuum-assisted resin transfer method [10,18], gluing and vacuuming [11,13], gluing and pressing [19], and hot pressing [12], to using the resin employed for the core $[15,17]$ or using the resin employed for the skin and pressing [16].

In the field of construction materials, the sandwich or multi-layered structures are commonly used as wall panels. Brenci et al. [21] designed several multi-layered wall structures consisting of different core materials, such as wood shavings, recycled acrylonitrile butadiene styrene (ABS), and rock wool as well as different face plates such as oriented strand board and gypsum board. Buratti et al. [22] studied a multi-layered wall panel consisting of a straw core and an air gap fixed between wooden plates, with the assembly being plastered on both faces. La Rosa et al. [23] evaluated different types of wall systems. Some of the wall structures were formulated with an eco-sandwich panel, consisting of a cork core and flax fibers-epoxy resin composite skin.

Besides the wall structures, sandwich panels are being used as acoustic or thermal insulations. Ricciardi et al. [24] prepared a hybrid sandwich panel consisting of recycled paper core and recycled textile fibers (polyethylene) based skins. The 12-mm and 20-mm thick panels were assessed regarding their thermal and acoustic properties. It was observed that thermal conductivity varies between $0.034-0.039 \mathrm{~W} / \mathrm{m} \cdot \mathrm{K}$, and the noise reduction coefficient is between $0.23-0.38$. Moreover, after conducting a life cycle assessment of the panels, it was evident that these sandwich composites have a high environmental impact, regarding the energy consumption and global warming potential.

The aim of this paper is to discuss the performance of a natural material-based sandwich panel, which would find its application as an acoustic absorption and airborne sound insulation material, with a proper thermal conductivity, having comparable characteristics with synthetic materials. As far as the authors are concerned, this is the first sheep wool-based sandwich panel using only natural materials. The structure is designed using hydrated lime, rice paste, and wool fibers for the face sheets and hydrated lime, wheat flour, and wool fibers for the core. On the prepared composite, different tests were effectuated, including acoustical, thermal, and mechanical determinations in order to evaluate its suitability as an insulation material. 


\section{Materials and Methods}

\subsection{Materials}

The aim of this paper is to obtain a natural panel of comparable acoustic performances with the synthetic ones, destined for indoor spaces. Natural materials are known to have a positive impact on human health and psyche [25] and to regulate indoor temperature and humidity [26].

For the preparation of the sandwich panel's face sheets, the following materials were used: hydrated lime (type CL80-S), commercially available wool fibers, rice paste, and water. The wool fibers were obtained from the Romanian sheep breed "ţigaie." This type of wool fiber is characterized by fineness and a high degree of crimps, so it is mainly used in the textile industry. The fibers were not chemically treated due to environmental considerations. The wool was only washed and carded. The carded wool mats were cut, which resulted in fibers with a length of $1-10 \mathrm{~mm}$. The rice paste was prepared by boiling a mixture of ground rice grains and water. The maximum dimension of the rice granules was $1 \mathrm{~mm}$ and the ratio of granules to water was 0.125 . Several properties of the sandwich panel's face sheets were reported elsewhere $[27,28]$. The recipe of the composite can be observed in Table 1.

Table 1. The recipes of one of the face sheets, the binder used for the core, and the core of the sandwich panels, respectively.

\begin{tabular}{|c|c|c|c|c|c|c|}
\hline \multicolumn{2}{|c|}{ Material } & $\begin{array}{l}\text { Rice Paste } \\
\text { (g) }\end{array}$ & $\begin{array}{l}\text { Hydrated } \\
\text { Lime (g) }\end{array}$ & $\begin{array}{c}\text { Wool } \\
\text { Fibers (g) }\end{array}$ & $\begin{array}{c}\text { Water } \\
(\mathrm{mL})\end{array}$ & $\begin{array}{l}\text { Wheat } \\
\text { Flour }(g)\end{array}$ \\
\hline 1 & $\begin{array}{l}\text { Face } \\
\text { sheet }\end{array}$ & 821.1 & 2395.3 & 61.2 & 1317.5 & - \\
\hline \multirow{2}{*}{2} & Core & - & - & 600 & - & - \\
\hline & Binder & - & 609 & - & 2878 & 263 \\
\hline
\end{tabular}

In order to prepare the sandwich panel's core, the following materials were used: wool fibers, hydrated lime, wheat flour, and water. The wool fibers and hydrated lime have the same properties as those used for the preparation of the face sheets, with the exception that the wool mats used for the core preparation were cut, according to the final dimensions of the panel. The wheat flour used is commercially available, marketed as "type 000 ," which has the finest granulation available. The recipe of the core and the binder can be observed in Table 1.

\subsection{Preparation of Samples}

In total, nine panels with the dimensions of $595 \mathrm{~mm} \times 350 \mathrm{~mm} \times 50 \mathrm{~mm}$ (for the determination of airborne sound insulation), four cylindrical samples with the diameter of $63.5 \mathrm{~mm}$ and height of $50 \mathrm{~mm}$ (for the determination of sound absorption) were prepared. One panel was cut to obtain the samples for the determination of mechanical $(150 \mathrm{~mm} \times 150 \mathrm{~mm} \times 50 \mathrm{~mm}$ and $150 \mathrm{~mm} \times 300 \mathrm{~mm} \times$ $50 \mathrm{~mm})$ and thermal $(150 \mathrm{~mm} \times 150 \mathrm{~mm} \times 50 \mathrm{~mm})$ properties.

The preparation of samples was carried out both mechanically and manually. First, the cores were manufactured by using the following steps: laying out the fiber mats on a flat surface, pulverizing half of the quantity of the binder over the fibers with a pressure sprayer, carefully turning the fiber mats with their unsprayed side up, pulverizing the remaining binder over the fibers, placing the binder-fiber assembly into molds with dimension of $595 \mathrm{~mm} \times 350 \mathrm{~mm} \times 30 \mathrm{~mm}$, and applying a pressure to the samples. The samples were turned over periodically (at intervals of 2-3 days) to aid their ventilation and drying process. The cores were kept in standard conditions until one of the skins was cast.

The casting of the skins started when the cores had dried to the point that they could be easily manipulated. The two skins were cast separately. The composite was prepared by mechanical mixing. A mold with the dimensions of $595 \mathrm{~mm} \times 350 \mathrm{~mm} \times 50 \mathrm{~mm}$ was prepared in which a 10-mm thick layer was cast. The $30-\mathrm{mm}$ thick core was placed on top of the fresh composite. The contact surface 
of the core with the skin was previously sprayed with the binder used to prepare the core itself to improve its adhesion to the skin. A rigid 10-mm thick sheet was placed over the core to completely fill the mold and the mold was pressed. When the second skin was cast, the pressure and the rigid sheet were removed. Before applying the second skin, the surface of the core was again sprayed with the binder used for the core. Then a layer of 10-mm thickness was evenly distributed over the core. The sandwich structure was again pressed. The panels were unmolded and the pressure was removed after 3 days. In the following period of time, the panels were regularly turned for 1-2 weeks in standard conditions (temperature of $24{ }^{\circ} \mathrm{C} \pm 2{ }^{\circ} \mathrm{C}$ and relative humidity of $60 \% \pm 5 \%$ ) to help the drying process. The prepared sandwich structure is presented in Figure 1.

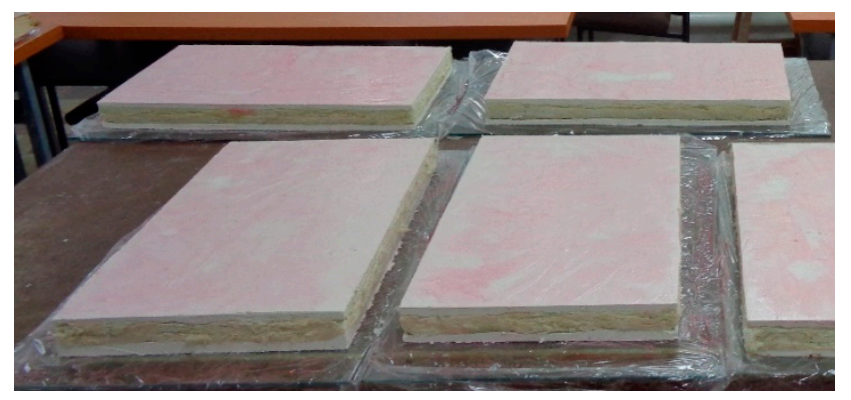

(a)

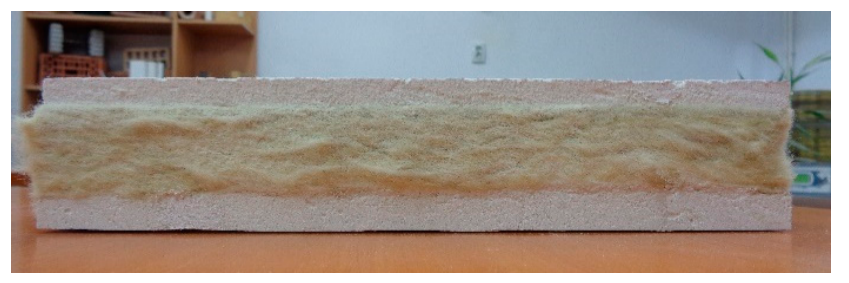

(b)

Figure 1. The prepared sandwich panels: (a) Overview of the full-sized panels and (b) cross section.

For the preparation of cylindrical samples, the same method was followed, but on a smaller scale. Three of the samples had one of its skins perforated in order to evaluate the sample's sound absorption. The perforation ratios were: $10 \%, 20 \%$, and $30 \%$, with the perforation diameter being $10 \mathrm{~mm}$. Based on the studies realized in the Patent Application no. "a 2018 00288"/24.04.2018, it was concluded that the perforations with a larger diameter develop better acoustic absorption performances on the entire frequency range. An unperforated control sample was also prepared. The prepared samples are presented in Figure 2.

In order to assess the sandwich structure's airborne sound insulation and sound reduction index, a panel with the dimensions of $1500 \mathrm{~mm} \times 1250 \mathrm{~mm}$ had to be constructed. Eight prepared panels with dimensions of $595 \mathrm{~mm} \times 350 \mathrm{~mm} \times 50 \mathrm{~mm}$ were fixed through 30 -mm width battens inside a wooden frame $50 \mathrm{~mm}$ in height. In order to avoid acoustic bridges created by the frame, an elastic band of 18-mm width was applied under the wooden fixing battens. The details of the panel are presented in Figure 3.

\subsection{Methods of Determination}

The prepared sandwich composite was subjected to the following determinations: sound absorption, airborne sound insulation, thermal conductivity, thermal resistance, compressive strength, and flexural strength. 


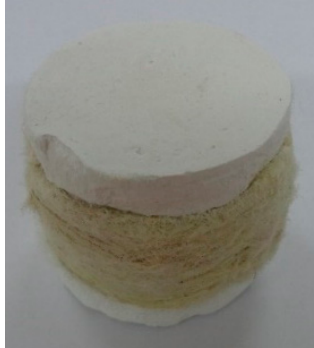

(a)

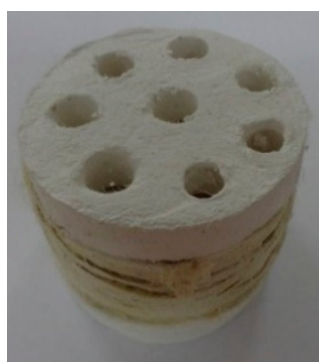

(c)

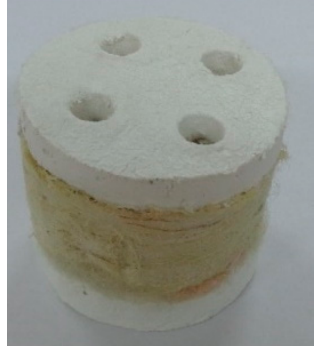

(b)

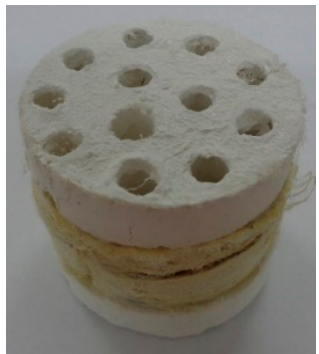

(d)

Figure 2. Samples for acoustic absorption with different perforation ratios: (a) $0 \%$, (b) $10 \%$, (c) $20 \%$, and (d) $30 \%$.

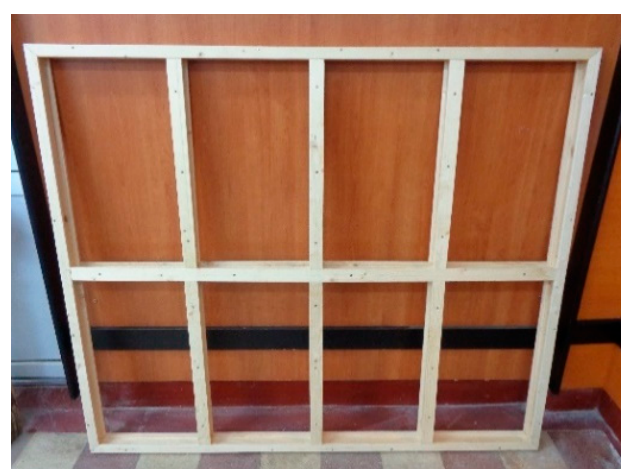

(a)

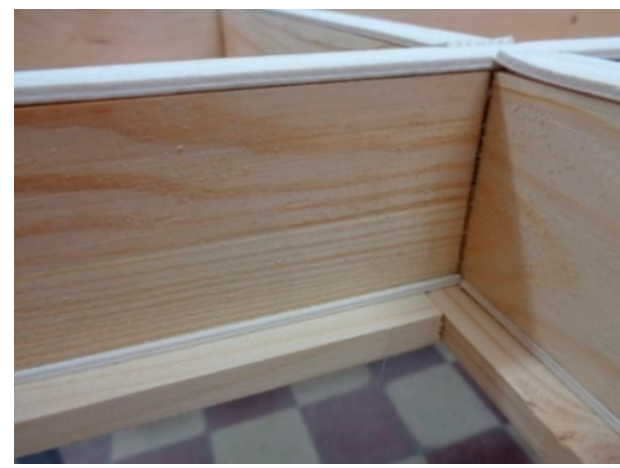

(b)

Figure 3. Details of the panel prepared for airborne sound insulation: (a) wooden frame and (b) detail of elastic band applied under the battens.

The determination of the sound absorption coefficient was carried out according to SR EN ISO 10534-2 [29], using an impedance tube type 4206A (Brüel\&Kjær, Nærum, Denmark). The results were recorded for the frequency band of $100-3.2 \mathrm{kHz}$, with the help of the transfer function method. For this determination, four types of samples were prepared with the diameter of $63.5 \mathrm{~mm}$ in order to fit inside the impedance tube's sample holder and thickness of $50 \mathrm{~mm}$, which have different percentages of skin perforations: $0 \%, 10 \%, 20 \%$, and $30 \%$. The noise reduction coefficient (NRC) was also calculated using Equation (1) [30].

$$
\mathrm{NRC}=\frac{\alpha_{250}+\alpha_{500}+\alpha_{1000}+\alpha_{2000}}{4}[-]
$$

The determination of airborne sound insulation (Figure 4) was carried out according to SR EN ISO 10140-2 [31]. For this determination, a panel with the dimensions of $1500 \mathrm{~mm} \times 1250 \mathrm{~mm} \times 50 \mathrm{~mm}$ was prepared. The panel can be observed in Figure 4 . The weighted sound reduction index, $R_{\mathrm{W}}$, was calculated according to SR EN ISO 717-1 [32]. 


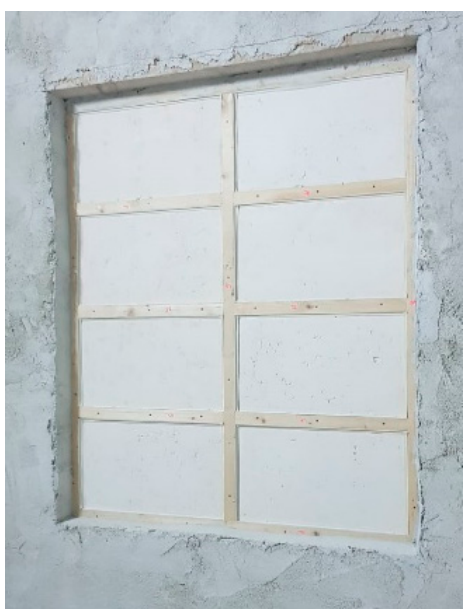

(a)

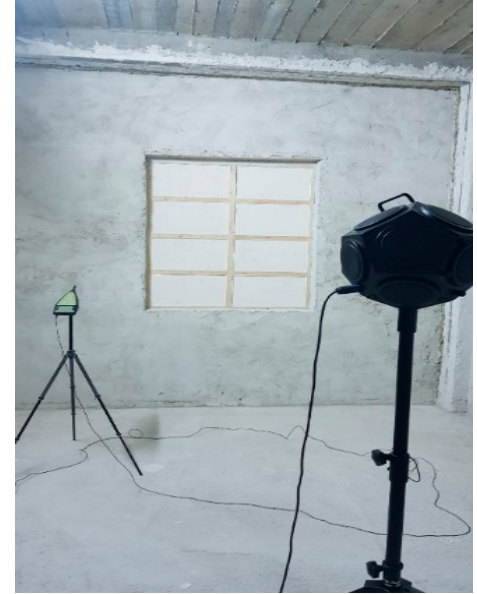

(b)

Figure 4. Determination of airborne sound insulation: (a) The prepared insulating panel and (b) the installed system for the determination.

The determination of the thermal conductivity coefficient and thermal resistance was carried out according to SR EN 12664 [33], using a heat flow meter type FOX 200 (TA Instruments, New Castle, DE, USA). For this determination, a sample with the dimensions of $150 \mathrm{~mm} \times 150 \mathrm{~mm} \times 50 \mathrm{~mm}$ was prepared. The sample was dried in standard conditions. The drying process being considered was complete when the difference between two successive weighing was smaller than $0.1 \mathrm{~g}$. The thermal properties were evaluated at a temperature of $20^{\circ} \mathrm{C}$.

The determination of mechanical strength (Figure 5) was carried out according to SR EN 826 [34] for the compressive strength and SR EN 12089 [35] for the bending strength. A universal testing machine type ZD10-90 (Fritz Heckert, Dolnoślaskie, Poland) was employed to perform the mechanical experiments. The dimensions of the prepared samples were of $150 \mathrm{~mm} \times 150 \mathrm{~mm} \times 50 \mathrm{~mm}$ for the compressive strength test and $150 \mathrm{~mm} \times 300 \mathrm{~mm} \times 50 \mathrm{~mm}$ for the bending test, respectively.

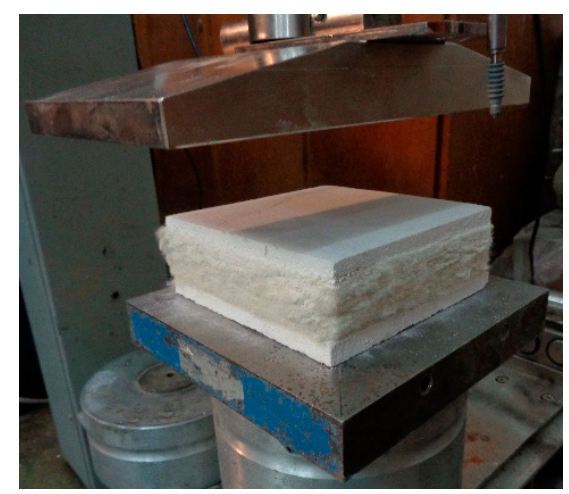

(a)

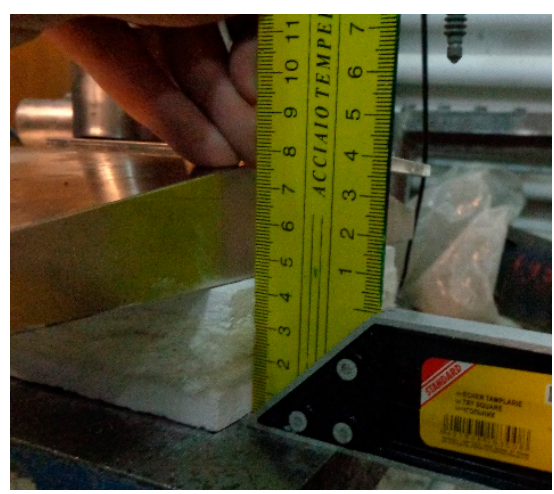

(b)

Figure 5. Determination of compressive strength: (a) sample before the determination and (b) sample during the determination.

\section{Results and Discussion}

\subsection{Sound Absorption}

In order to evaluate the panel's acoustic absorption, four types of samples were tested with one of their face sheets perforated, as follows: P0-unperforated, $\mathrm{P} 1$-with 10\% perforations, $\mathrm{P} 2$-with 20\% perforations, and $\mathrm{P} 3$-with $30 \%$ perforations. The acoustic absorption of the core was also assessed (PC). The obtained results represent the mean value of three different measurements due to the core 
non-uniformity. The variation of the acoustic absorption coefficient as a function of frequency is shown in Figure 6.

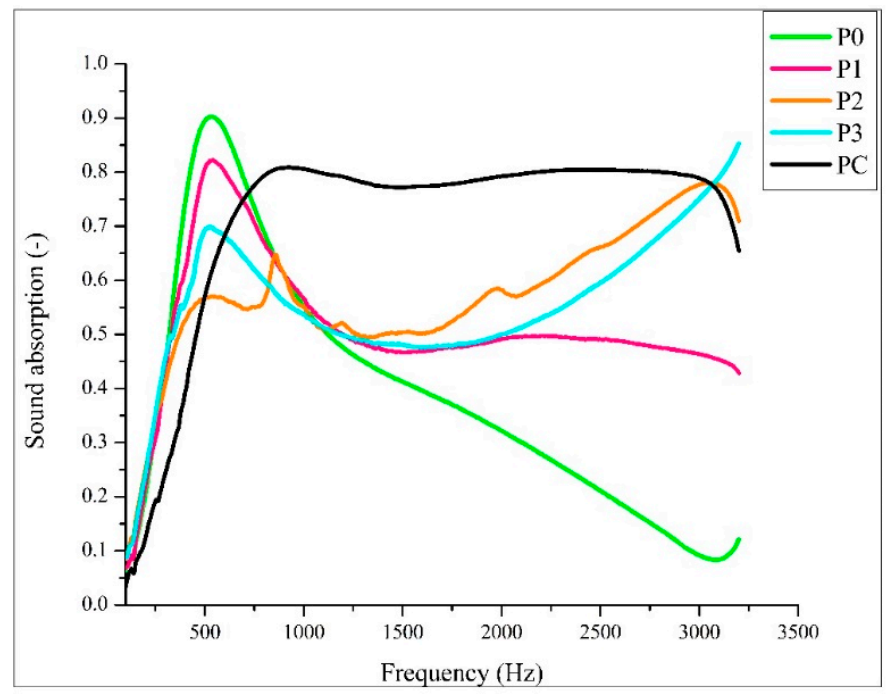

Figure 6. Variation of the sound absorption coefficient as a function of frequency of the tested samples.

From the obtained results (Figure 6), it can be observed that the maximum value of sound absorption $\left(\alpha_{\max }\right)$ decreases with an increasing perforation percentage for the samples P0-P2, but, for the sample P3, the maximum value increases. Even with three measurements effectuated, the trend of the sample P2 seems to be influenced by the core non-uniformity. The registered curve of the absorption is almost linear for the core (sample PC) at frequencies higher than $916 \mathrm{~Hz}$, which corresponds to the maximum value of sound absorption. The curves of P0 and P1 have their peak values at around $500 \mathrm{~Hz}$, after which the absorption decreases. In the case of P2 and P3, the absorption peaks shifted toward the frequency of $3000 \mathrm{~Hz}$, but still maintained increased values at lower frequencies. Regarding the values of NRC (Table 2), PC shows the highest values, being followed by P1, but all the samples exhibit close values to that of the core.

Table 2. NRC values of the tested samples compared to glass wool (GW) with a thickness of $25 \mathrm{~mm}$ and expanded polystyrene (EPS) with a thickness of $25 \mathrm{~mm}$ [36].

\begin{tabular}{cccccccc}
\hline Sample & P0 & P1 & P2 & P3 & PC & GW & EPS \\
\hline NRC $(-)$ & 0.521 & 0.543 & 0.512 & 0.521 & 0.590 & 0.57 & 0.275 \\
\hline
\end{tabular}

Thus, the influence of perforations and perforation ratios is significant. First, with perforations, the maximum value of acoustic absorption decreases. Second, by increasing the percentage of perforations, the absorption peak is shifted toward higher frequencies. Third, there is no significant influence of the perforation's percentage on NRC. However, their positive influence is evident in the case of P0-P1.

In the literature, the available data on natural fiber-based sandwich panels' acoustic performance is scarce, but there are a few studies regarding the determination of acoustic absorption of hybrid composites. Zulkifli et al. [37] evaluated the acoustical properties of a multi-layered panel consisting of treated coconut coir fiber core and coconut fiber-polyester resin composite skin. The obtained results show that the highest values of sound absorption are between $0.70-0.80$ for the frequencies of 1000-1800 Hz. Huang et al. [38] prepared a multilayered composite by needle punching and thermal bonding, which consists of polyester fibers and coconut fibers laid alternatively in several layers. The average sound absorption coefficient of the panel was situated between 0.604-0.711. Wang et al. [39] studied the acoustical properties of a multi-layered composite made by hot-pressing from sisal fibers-polyurethane based composite and polyethylene film, laid alternatively in several 
layers. It was found that the maximum sound absorption coefficient of the composite can reach 0.71 at the frequency of $3150 \mathrm{~Hz}$.

The performance of the tested samples compared to synthetic materials, which is expanded polystyrene (EPS) and glass wool (GW) [36], is presented in Figure 7. It can be observed that, at almost all frequencies (exception being P0 at $125 \mathrm{~Hz}, \mathrm{P} 1$ at $125 \mathrm{~Hz}, \mathrm{PC}$ at $125 \mathrm{~Hz}$, and PC at $250 \mathrm{~Hz}$ ), the samples have a higher acoustic absorption than EPS. On the other hand, the sandwich samples (P0, P1, P2, and P3) at $250 \mathrm{~Hz}$ and $500 \mathrm{~Hz}$ showed higher values than GW. Furthermore, the values of PC (the core without face sheets, with a thickness of $30 \mathrm{~mm}$ ) are close to those of $\mathrm{GW}$, mainly at higher frequencies (exceeding the values of GW at frequencies of 500, 1000, and $2000 \mathrm{~Hz}$ ), which is an expected result, considering that both materials have a fibrous structure, which facilitates acoustic absorption. Regarding the values of NRC, the measured values of the sandwich samples are positioned between the values of EPS and GW, with the values of PC being higher than the values of both synthetic materials.

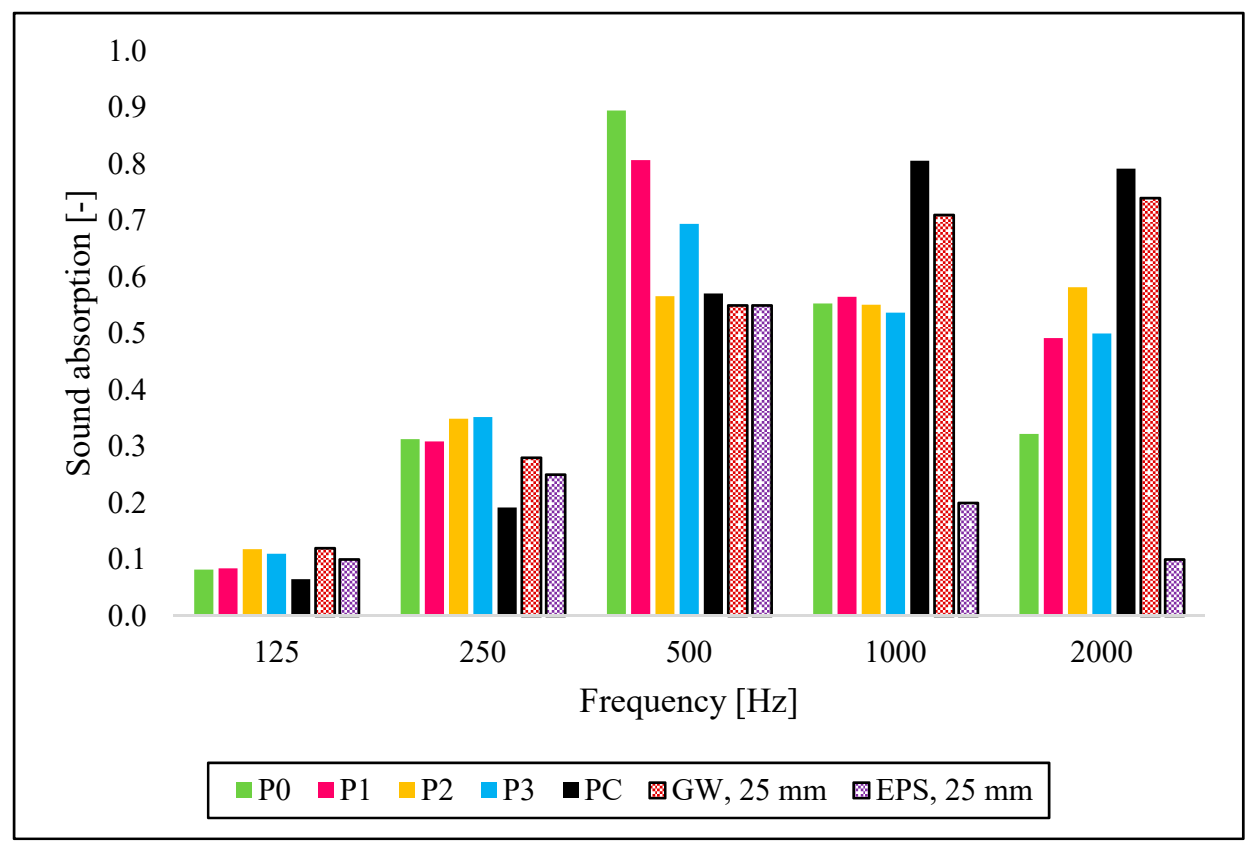

Figure 7. Variation of sound absorption according to standardized frequency bands of the tested samples compared to glass wool (GW) with a thickness of $25 \mathrm{~mm}$ and expanded polystyrene (EPS) with a thickness of $25 \mathrm{~mm}$.

\subsection{Airborne Sound Insulation}

The determination of the sound attenuation indices, $R_{\mathrm{i}}(\mathrm{f})$, was made with Equation (2) [31].

$$
R_{\mathrm{i}}(\mathrm{f})=\mathrm{L}_{1}-\mathrm{L}_{2}+10 \lg \frac{\mathrm{S}}{\mathrm{A}}(\mathrm{dB})
$$

where: $\mathrm{L}_{1}$-sound pressure level in the source room $(\mathrm{dB}), \mathrm{L}_{2}$ - sound pressure level in the receiving room $(\mathrm{dB}), \mathrm{S}$ - the panel's surface $\left(\mathrm{m}^{2}\right), \mathrm{A}$ - the equivalent absorption area $\left(\mathrm{m}^{2}\right)$.

The weighted sound reduction index, $R_{\mathrm{W}}$, was obtained according to the provisions stipulated in Reference [32] by comparing the curve of the sound attenuation indices with the reference curve.

The results of the airborne sound insulation test can be observed in Figure 8. Besides the measured curve, $R_{\mathrm{i}}$, there are also reference and translated curves presented, respectively. The value of airborne sound insulation follows the "mass law." The greater the mass of the insulating element, the greater the value of sound insulation. In order to achieve a sample with the highest mass, the perforations of the face sheet were neglected. 


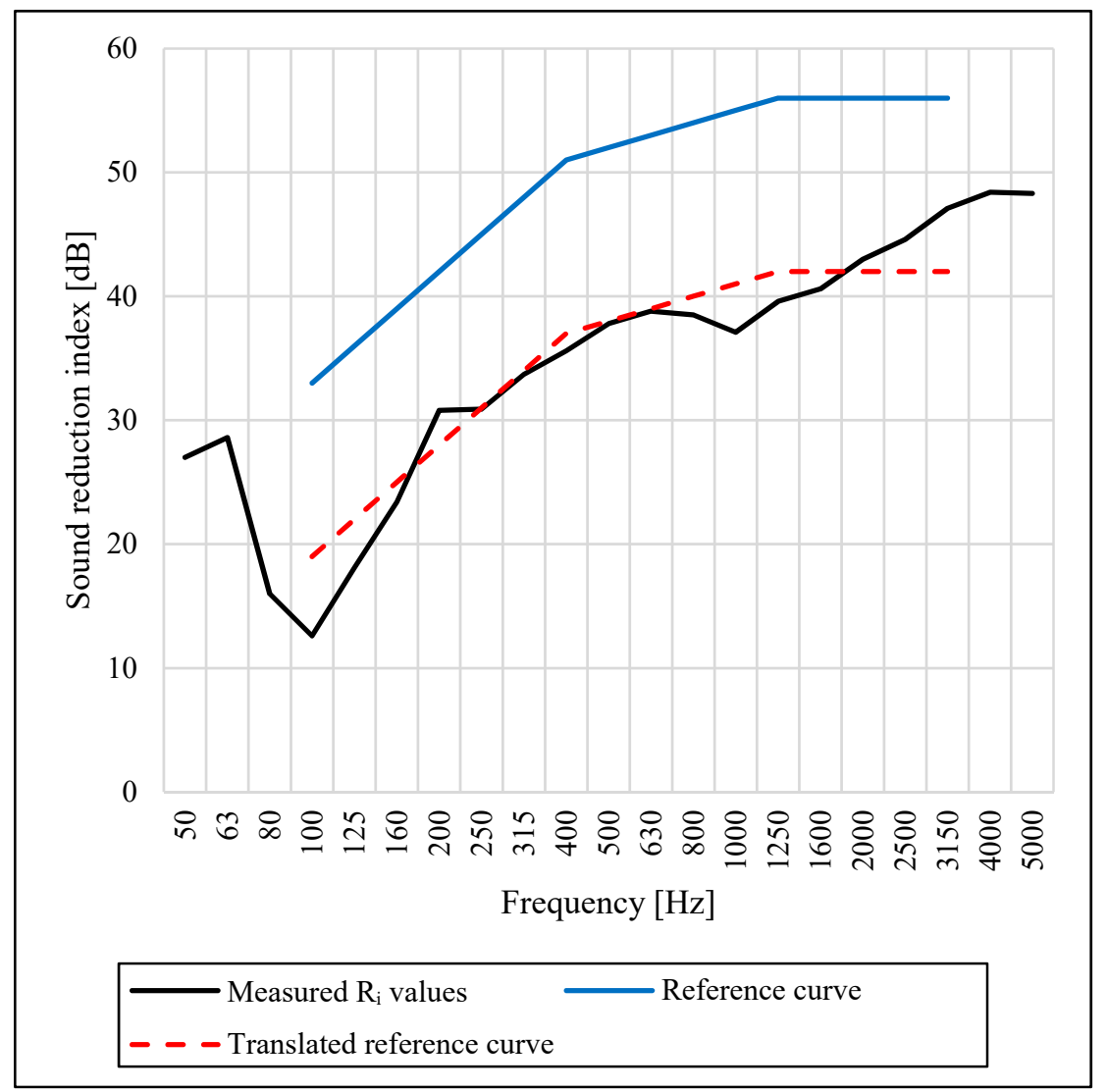

Figure 8. Values of measured sound reduction index, reference curve, and translated reference curve as a function of frequency.

The tested panel has a value of weighted sound reduction index, $R_{w}\left(C ; C_{t r}\right)$, of $38(-2 ;-8) d B$. Díaz et al. [40] studied the airborne sound insulation of a natural sandwiched panel of reed core and MDF (medium density fiberboard) skins. The authors found that the 82-mm thick panel has its weighted sound reduction index of $39 \mathrm{~dB}$.

Most of the available multi-layered structures for airborne sound insulation are based on mineral wool. Such a sandwich structure, composed of a mineral wool core and gypsum board face sheets with a total thickness of $125 \mathrm{~mm}$, has its weighted sound reduction index of $41 \mathrm{~dB}$ [41].

\subsection{Thermal Conductivity and Thermal Resistance}

According to the Romanian Norm C107/2-2005 [42], a material can be considered thermal insulating if its thermal conductivity is lower than $0.065 \mathrm{~W} / \mathrm{m} \cdot \mathrm{K}$ and its thermal resistance is higher than $0.50 \mathrm{~m}^{2} \mathrm{~K} / \mathrm{W}$. Asdrubali et al. [43] suggests that the thermal conductivity value of insulating materials might be considered to be lower than $0.07 \mathrm{~W} / \mathrm{m} \cdot \mathrm{K}$.

The results of the determination of thermal conductivity and thermal resistance of the sandwich panel are presented in Table 3. It can be observed that the value of thermal resistance fulfills the requirement imposed by the national norm.

Table 3. Results of thermal parameters of the tested sample.

\begin{tabular}{cc}
\hline Parameter & Value \\
\hline Thermal conductivity $(\mathrm{W} / \mathrm{m} \cdot \mathrm{K})$ & 0.07699 \\
Apparent density $\left(\mathrm{g} / \mathrm{cm}^{3}\right)$ & 0.546 \\
Thermal resistance $\left(\mathrm{m}^{2} \mathrm{~K} / \mathrm{W}\right)$ & 0.6056 \\
Temperature $\left({ }^{\circ} \mathrm{C}\right)$ & 20 \\
\hline
\end{tabular}


The value of thermal resistance was calculated using Equation (3).

$$
R=\frac{\mathrm{d}}{\lambda}\left[\mathrm{m}^{2} \mathrm{~K} / \mathrm{W}\right]
$$

where: $\mathrm{d}$-thickness of the material (m), $\lambda$ —thermal conductivity of the material $(\mathrm{W} / \mathrm{m} \cdot \mathrm{K})$.

Huang et al. [38] determined both the acoustical and thermal properties of their studied structure, obtaining a value of thermal conductivity of $0.0279-0.0495 \mathrm{~W} / \mathrm{m} \cdot \mathrm{K}$. Efe et al. [44] investigated a sandwich structure made of whole sunflower stalks and epoxy resin core and MDF skins through hot-pressing. The value of thermal conductivity of the composite ranges between $0.045-0.060 \mathrm{~W} / \mathrm{m} \cdot \mathrm{K}$, according to the method of determination. Binici et al. [45] studied a multi-layered panel based on layers of sunflower stem, cotton waste, and textile waste bound with epoxy resin. The resulting composites had low thermal conductivity where the value ranges from 0.2616 to $0.0728 \mathrm{~W} / \mathrm{m} \cdot \mathrm{K}$.

Synthetic materials, such as EPS and GW, are preferred over natural materials due to their low thermal conductivity. In general, thermal conductivity varies between $0.031-0.038 \mathrm{~W} / \mathrm{m} \cdot \mathrm{K}$ for EPS and between $0.031-0.037 \mathrm{~W} / \mathrm{m} \cdot \mathrm{K}$ for GW, for densities of $15-35 \mathrm{~kg} / \mathrm{m}^{3}$ for EPS and $15-75 \mathrm{~kg} / \mathrm{m}^{3}$ for GW [46]. Usually, the thermal insulating property of a material is aided by the entrapped air between the fibers or cells since air has a low thermal conductivity. Thus, the density of these materials is also reduced.

In spite of the sandwich composite having relatively high apparent density $\left(546 \mathrm{~kg} / \mathrm{m}^{3}\right)$, it still presents low thermal conductivity. This fact might be attributed to the hollow structure of wool fiber. The core of the fibers, which are also called medulla, is a canal filled with air [47]. The fibers are also present in the face sheets, which further could contribute to lowering the thermal conductivity of the sandwich structure. Furthermore, it was demonstrated that the thermal conductivity of wool assemblies decreases as their density increases [48].

\subsection{Compressive Strength}

The results of the determination of compressive strength are presented in Figure 9 and Table 4. It can be observed from Figure 9 that the sandwich panel has a highly elastic behavior. The variation of displacement as a function of the applied load is almost linear between 1-4 mm. Moreover, after removing the applied load, the sandwich panel regained $80 \%$ of its original thickness.

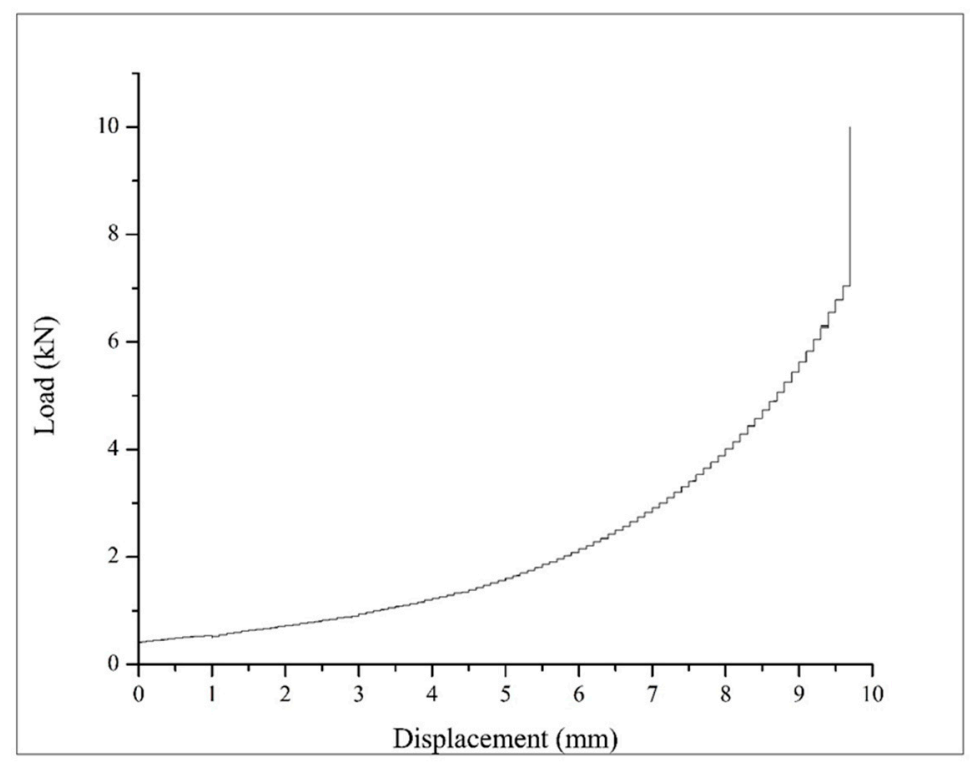

Figure 9. Variation of displacement as a function of the applied compressive load. 
Table 4. Compressive strength and other parameters of the tested sample.

\begin{tabular}{cc}
\hline Parameter & Value \\
\hline Relative deflection of $10 \%(\mathrm{~mm})$ & 5 \\
Applied load afferent to the relative deflection of $10 \%(\mathrm{kN})$ & 1.559 \\
Compressive strength afferent to the relative deflection of $10 \%(\mathrm{MPa})$ & 0.208 \\
\hline
\end{tabular}

Binici et al. [45] presented their hybrid thermal insulating panel, but the composite had low compressive strength. They reported values of compressive strength that varies between 0.283-0.312 MPa.

The tested panel has higher compressive strength than commercially available EPS and GW. A commercially available 50-mm thick EPS sheet usually has a compressive strength between 0.05-0.10 MPa. Products of stone wool were subjected to the determination of compressive strength by Buska and Mačiulaitis [49]. It was found that their strength varies between 0.0475-0.0574 MPa. Referring to these values, the results obtained in the present study are higher, which might be attributed to the high compressive strength of the face sheets reported elsewhere [27].

\subsection{Bending Strength}

The results of the determination of bending strength are presented in Figure 10 and Table 5. It can be observed that the bending strength has a value of $0.042 \mathrm{MPa}$ and the maximum deflection is $7.5 \mathrm{~mm}$.

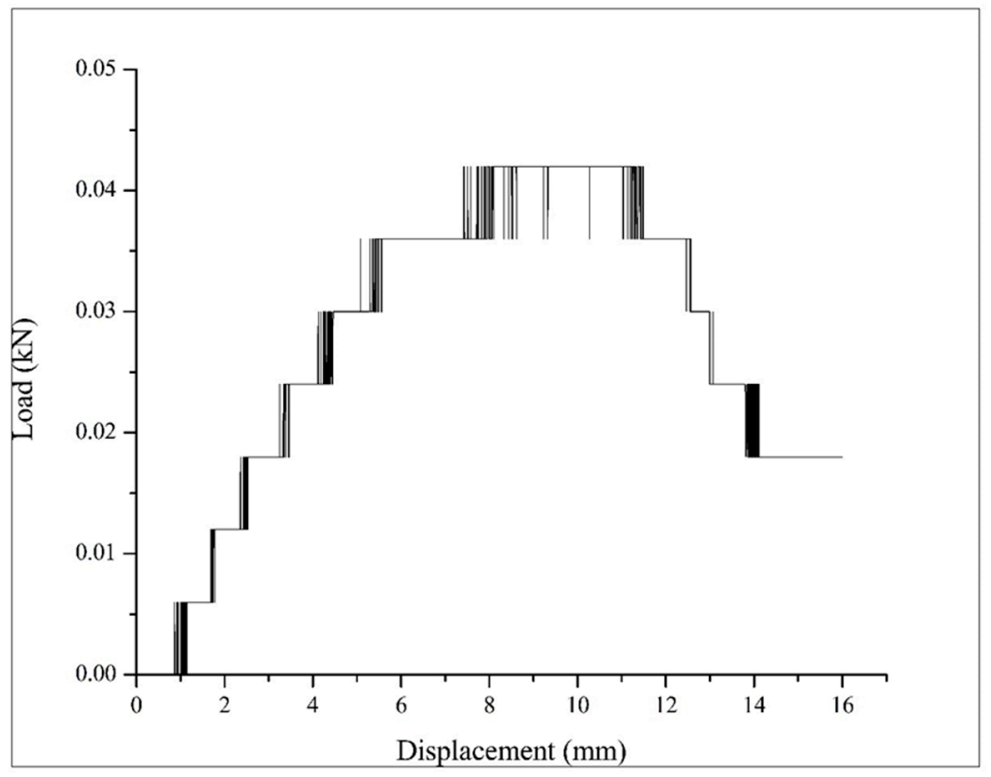

Figure 10. Variation of displacement as a function of the applied bending load.

Table 5. Bending strength and other parameters of the tested sample.

\begin{tabular}{cc}
\hline Parameter & Value \\
\hline Maximum load (kN) & 0.042 \\
Deflection (mm) & 7.5 \\
Distance between support edges (mm) & 250 \\
Bending strength (MPa) & 0.042 \\
\hline
\end{tabular}

Yang et al. [50] prepared a sandwich panel by hot pressing, which consisted of bamboo chips based corrugated particleboard core laminated between two face plates of MDF. After evaluating the multi-layered panel's mechanical properties, it was observed that the bending properties increase with increasing density of the panel. 
Binici et al. [45] also presented their results regarding the flexural strength of some samples, with the value varying between $0.06-0.09 \mathrm{MPa}$. Regarding the synthetic materials, the bending strength of EPS is around $0.075-0.25 \mathrm{MPa}$ [51].

\section{Conclusions}

In this work, a natural materials-based sandwich panel was prepared and studied. The panel is proposed to be used as a sound absorbing and airborne sound insulating solution. Based on the presented experimental study, the following conclusions can be drawn.

- The sound absorption of the sandwich panel depends on the ratio of skin perforations. The maximum values vary between $0.708-0.903$, which are very high values in the category of natural sandwich composites;

- The measured weighted sound reduction index of the panel was of $38 \mathrm{~dB}$;

- Thermal conductivity of the sandwich panel $(0.07699 \mathrm{~W} / \mathrm{m} \cdot \mathrm{K})$ was low;

- Mechanical strength of the panels was comparable to the reported values in the literature (compressive strength of $0.208 \mathrm{MPa}$ and bending strength of $0.042 \mathrm{MPa}$ ), considering that only natural materials were used in the manufacturing process of the panels.

It can be concluded that the studied sandwich structure could be optimized regarding its mechanical properties, without compromising its acoustical or thermal performance, which will be the aim of the authors' future works. Other future research works would also assess the panel's resistance to the attack of microorganisms, and its durability in indoor environments with high moisture content. Based on the current results, it is suggested that this panel would be suitable as applied cladding or an independent lightweight partition wall, since the presented sandwich structure has good acoustic characteristics.

Author Contributions: Conceptualization, D.-R.T.-G. and T.-O.D. Methodology and investigation, D.-R.T.-G., T.-O.D., R.I., A.E.T., D.L.M., and O.V. Project administration, D.-R.T.-G. Writing-original draft preparation, T.-O.D. Revised the manuscript, D.-R.T.-G., T.-O.D., R.I., and A.E.T. All authors have read and agreed to the published version of the manuscript.

Funding: The results presented in this paper were obtained in the framework of the GNaC 2018 ARUT grant "Innovative solutions for the acoustic comfort in open space offices," research Contract no. 3223/06.02.2019, with the financial support of the Technical University of Cluj-Napoca.

Conflicts of Interest: The authors declare no conflict of interest.

\section{References}

1. Krus, M.; Theuerkorn, W.; GroBinski, T.; Künzel, H. New sustainable and insulating building material made of cattail. Full Pap. NSB 2014, 1252-1260.

2. Faustino, J.; Pereira, L.; Soares, S.; Cruz, D.; Paiva, A.; Varum, H.; Ferreira, J.; Pinto, J. Impact sound insulation technique using corn cob particleboard. Constr. Build. Mater. 2012, 37, 153-159. [CrossRef]

3. Mishra, S.P.; Nath, G. Synthesis and analysis of acou-physical properties of banana biocomposite. In Proceedings of the IOP Conference Series: Materials Science and Engineering, Istanbul, Turkey, 8 August 2018; IOP Publishing: Bristol, UK, 2018; Volume 310.

4. Kinnane, O.; Reilly, A.; Grimes, J.; Pavia, S.; Walker, R. Acoustic absorption of hemp-lime construction. Constr. Build. Mater. 2016, 122, 674-682. [CrossRef]

5. Trematerra, A.; Antonio, M.; Iannace, G. Use of green material for acoustic correction inside rooms. J. Sustain. Archit. Civ. Eng. 2013, 3, 33-38. [CrossRef]

6. Faruk, O.; Bledzki, A.K.; Fink, H.-P.; Sain, M. Biocomposites reinforced with natural fibers: 2000-2010. Prog. Polym. Sci. 2012, 37, 1552-1596. [CrossRef]

7. Kymäläinen, H.-R.; Sjöberg, A.-M. Flax and hemp fibres as raw materials for thermal insulations. Build. Environ. 2008, 43, 1261-1269. [CrossRef]

8. Genc, G.; Koruk, H. Identification of the dynamic characteristics of luffa fiber reinforced bio-composite plates. Bioresources 2017, 12, 5358-5368. [CrossRef] 
9. D'Alessandro, V.; Petrone, G.; Franco, F.; De Rosa, S. A review of the vibroacoustics of sandwich panels: Models and experiments. J. Sandw. Struct. Mater. 2013, 15, 541-582. [CrossRef]

10. Prabhakaran, S.; Krishnaraj, V.; Shankar, K.; Senthilkumar, M.; Zitoune, R. Experimental investigation on impact, sound, and vibration response of natural-based composite sandwich made of flax and agglomerated cork. J. Compos. Mater. 2019. [CrossRef]

11. Sargianis, J.J.; Kim, H.I.; Andres, E.; Suhr, J. Sound and vibration damping characteristics in natural material based sandwich composites. Compos. Struct. 2013, 96, 538-544. [CrossRef]

12. Zhang, J.; Shen, Y.; Jiang, B.; Li, Y. Sound absorption characterization of natural materials and sandwich structure composites. Aerospace 2018, 5, 75. [CrossRef]

13. Sargianis, J.; Kim, H.I.; Suhr, J. Natural cork agglomerate employed as an environmentally friendly solution for quiet sandwich composites. Sci. Rep. 2012, 2, 403. [CrossRef] [PubMed]

14. Bach, M.R.; Chalivendra, V.B.; Alves, C.; Depina, E. Mechanical characterization of natural biodegradable sandwich materials. J. Sandw. Struct. Mater. 2017, 19, 482-496. [CrossRef]

15. Cosereanu, C.; Lica, D.; Curtu, I.; Lunguleasa, A.; Cismaru, I.; Brenci, L.M.; Fotin, A. Mechanical testing of beech veneer sandwich composites. In Proceedings of the 7th International Conference of DAAAM Baltic Industrial Engineering, Tallinn, Estonia, 22-24 April 2010; pp. 0417-0422.

16. Ude, A.U.; Ariffin, A.K.; Azhari, C.H. An experimental investigation on the response of woven natural silk fiber/epoxy sandwich composite panels under low velocity impact. Fibers Polym. 2013, 14, 127-132. [CrossRef]

17. Dhas, E.R.; Pradeep, P. Mechanical property evaluation of palm/glass sandwiched fiber reinforced polymer composite in comparison with few natural composites. In Proceedings of the IOP Conference Series: Materials Science and Engineering, Bali, Indonesia, 1-2 April 2016; IOP Publishing: Bristol, UK, 2017; Volume 247, p. 012010.

18. Pandita, S.D.; Yuan, X.; Manan, M.A.; Lau, C.H.; Subramanian, A.S.; Wei, J. Evaluation of jute/glass hybrid composite sandwich: Water resistance, impact properties and life cycle assessment. J. Reinf. Plast. Compos. 2014, 33, 14-25. [CrossRef]

19. Fajrin, J.; Zhuge, Y.; Bullen, F.; Wang, H. Flexural behaviour of hybrid sandwich panel with natural fiber composites as the intermediate layer. J. Mech. Eng. Sci. 2016, 10, 1968-1983. [CrossRef]

20. Fajrin, J.; Zhuge, Y.; Bullen, F.; Wang, H. The structural behavior of hybrid structural insulated panels under pure bending load. Int. J. Technol. 2017, 8, 777-788. [CrossRef]

21. Brenci, L.M.; Cosereanu, C.; Zeleniuc, O.; Georgescu, S.V.; Fotin, A. Thermal conductivity of wood with ABS waste core sandwich composites subject to various core modifications. BioResources 2018, 13, 555-568. [CrossRef]

22. Buratti, C.; Belloni, E.; Merli, F.; Zanella, V.; Robazza, P.; Cornaro, C. An innovative multilayer wall composed of natural materials: Experimental characterization of the thermal properties and comparison with other solutions. Energy Procedia 2018, 148, 892-899. [CrossRef]

23. La Rosa, A.D.; Recca, A.; Gagliano, A.; Summerscales, J.; Latteri, A.; Cozzo, G.; Cicala, G. Environmental impacts and thermal insulation performance of innovative composite solutions for building applications. Constr. Build. Mater. 2014, 55, 406-414. [CrossRef]

24. Ricciardi, P.; Belloni, E.; Cotana, F. Innovative panels with recycled materials: Thermal and acoustic performance and Life Cycle Assessment. Appl. Energy 2014, 134, 150-162. [CrossRef]

25. Balador, Z.; Gjerde, M.; Isaacs, N.; Whitburn, S. Research hotspots on agro-waste based building insulation products-A meta-review. In Proceedings of the SB-LAB 2017, Porto, Portugal, 15-17 November 2017.

26. Nguyen, D.M.; Grillet, A.-C.; Diep, T.M.H.; Bui, Q.B.; Woloszyn, M. Influence of thermo-pressing conditions on insulation materials from bamboo fibers and proteins based bone glue. Ind. Crops Prod. 2018, 111, 834-845. [CrossRef]

27. Dénes, T.-O.; Tămaş-Gavrea, D.-R. Mechanical properties of lime based composites. Procedia Manuf. 2019, in press.

28. Tămaş-Gavrea, D.-R.; Dénes, T.-O. Mechanical, thermal, and acoustical properties of an innovative lime-wool composite. Procedia Manuf. 2019, in press.

29. SR EN ISO 10534-2:2002. Acoustics-Determination of Sound Absorption Coefficient and Impedance in Impedances Tubes_Part 2: Transfer-Function Method (ISO 10534-2:1998); ISO: Geneva, Switzerland, 2002. 
30. ASTM Standard C423. Standard Test Method for Sound Absorption and Sound Absorption Coefficients by the Reverberation Room Method; ASTM: West Conshohocken, PA, USA, 2017.

31. SR EN ISO 10140-2:2011. Acoustics—Laboratory Measurement of Sound Insulation of Building Elements-Part 2: Measurement of Airborne Sound Insulation; ISO: Geneva, Switzerland, 2011.

32. SR EN ISO 717-1:2013. Acoustics—Rating of Sound Insulation in Buildings and of Building Elements-Part 1: Airborne Sound Insulation; ISO: Geneva, Switzerland, 2013.

33. SR EN 12664:2002. Thermal Performance of Building Materials and Products. Determination of Thermal Resistance by Means of Guarded Hot Plate and Heat Flow Meter Methods. Dry and Moist Products of Medium and Low Thermal Resistance; CEN: Brussels, Belgium, 2002.

34. SR EN 826:2013. Thermal Insulating Products for Building Applications-Determination of Compression Behaviour; CEN: Brussels, Belgium, 2013.

35. SR EN 12089:2013. Thermal insulating Products For Building Applications-Determination of Bending Behaviour; CEN: Brussels, Belgium, 2013.

36. Absorption Coefficients. Available online: http://www.acoustic.ua/st/web_absorption_data_eng.pdf (accessed on 7 January 2020).

37. Zulkifli, R.; Mohd Nor, M.J.; Mat Tahir, M.F.; Ismail, A.R.; Nuawi, M.Z. Acoustic properties of multi-layer coir fibres sound absorption panel. J. Appl. Sci. 2008, 8, 3709-3714. [CrossRef]

38. Huang, C.-H.; Lin, J.-H.; Lou, C.-W.; Tsai, Y.-T. The efficacy of coconut fibers on the sound-absorbing and thermal-insulating nonwoven composite board. Fibers Polym. 2013, 14, 1378-1385. [CrossRef]

39. Wang, T.; Ge, H.; Wang, F. The sound absorption of sisal fiber and sisal fiber/polyethylene film sheets: Morphology and structure. Polym. Compos. 2018, 39, 2812-2818. [CrossRef]

40. Díaz, C.; Jiménez, M.; Navacerrada, M.Á.; Pedrero, A. Acoustic properties of reed panels. Mater. Constr. 2012, 62, 55-66. [CrossRef]

41. C125-2013. Normativ Privind Acustica în Construcţii şi Zone Urbane; MDRAP: Bucharest, Romania, 2013.

42. C107/2-2005. Normativ Privind Calculul Termotehnic al Elementelor de Construcție ale Clădirilor. Partea a 2-a: Normativ Privind Calculul Coeficienţilor Globali de Izolare Termică la Clădirile cu Altă Destinație Decât cea de Locuire; MDRAP: Bucharest, Romania, 2005.

43. Asdrubali, F.; D'Alessandro, F.; Schiavoni, S. A review of unconventional sustainable building insulation materials. Sustain. Mater. Technol. 2015, 4,1-17. [CrossRef]

44. Efe, F.T.; Alma, M.H. Investigating some physical properties of composite board, produced from sunflower stalks, designed horizontally. Ekoloji Derg. 2014, 23, 40-48. [CrossRef]

45. Binici, H.; Eken, M.; Dolaz, M.; Aksogan, O.; Kara, M. An environmentally friendly thermal insulation material from sunflower stalk, textile waste and stubble fibres. Constr. Build. Mater. 2014, 51, 24-33. [CrossRef]

46. Schiavoni, S.; D'Alessandro, F.; Bianchi, F.; Asdrubali, F. Insulation materials for the building sector: A review and comparative analysis. Renew. Sustain. Energy Rev. 2016, 62, 988-1011. [CrossRef]

47. Ammayappan, L. Eco-friendly surface modifications of wool fiber for its improved functionality: An overview. Asian J. Text. 2013, 3, 15-28. [CrossRef]

48. Ye, Z.; Wells, C.M.; Carrington, C.G.; Hewitt, N.J. Thermal conductivity of wool and wool-hemp insulation. Int. J. Energy Res. 2006, 30, 37-49. [CrossRef]

49. Buska, A.; Mačiulaitis, R. The compressive strength properties of mineral wool slabs: Influence of structure anisotropy and methodical factors. J. Civ. Eng. Manag. 2007, 13, 97-106. [CrossRef]

50. Yang, F.; Fei, B.; Wu, Z.; Peng, L.; Yu, Y. Selected properties of corrugated particleboards made from bamboo waste (Phyllostachys edulis) laminated with medium-density fiberboard panels. BioResources 2014, 9, 1085-1096. [CrossRef]

51. Technical Data. Available online: https://www.austrotherm.ro/descarcari/cataloage/ (accessed on 8 January 2020).

(C) 2020 by the authors. Licensee MDPI, Basel, Switzerland. This article is an open access article distributed under the terms and conditions of the Creative Commons Attribution (CC BY) license (http://creativecommons.org/licenses/by/4.0/). 